\title{
Association between serum ferritin and liver iron concentration with cardiac iron in pediatric thalassemia major patients
}

\author{
Antonella Meloni ${ }^{1 *}$, Maddalena Casale ${ }^{2}$, Aldo Filosa ${ }^{2}$, Maria Giovanna Neri ${ }^{1}$, Lorella Pitrolo ${ }^{3}$, Maria Paola Smacchia ${ }^{4}$, \\ Stefania Renne ${ }^{5}$, Antonino Vallone $^{6}$, Vincenzo Positano $^{1}$, Alessia Pepe ${ }^{1}$
}

From 19th Annual SCMR Scientific Sessions

Los Angeles, CA, USA. 27-30 January 2016

\section{Background}

Recently, the ability of LIC (liver iron concentration) and serum ferritin in predicting myocardial iron overload (MIO) has been challenged by magnetic Resonance Imaging (MRI) monitoring which demonstrated no or weak correlation between serum ferritin or LIC and MIO. Anyway, the role of this traditional markers could result particularly useful in pediatric population, where MRI assessment is difficult to carry out, because of early age, scarce collaboration or limited availability. So, we derived objective thresholds for these markers for predicting cardiac $\mathrm{T} 2 * 20 \mathrm{~ms}$ in pediatric patients.

\section{Methods}

From the 2171 patients with hemoglobinopathies enrolled in the MIOT (Myocardial Iron Overload in Thalassemia) network, we retrospectively selected 107 paediatric patients with thalassemia major (TM) (61 boys, median age 14.4 years).

MIO was assessed using a multislice multiecho $\mathrm{T}^{*}$ approach. Hepatic $\mathrm{T}^{*}$ values were assessed in a homogeneous tissue area and converted into LIC.

\section{Results}

Twenty-three patients (21.5\%) showed an abnormal global heart $\mathrm{T} 2 *$ value and none of them was under 7.9 years of age.

Serum ferritin was negatively correlated with global heart T2* values $(r=-0.425 ; \mathrm{p}<0.0001)$. Using ROC curve analysis, a serum ferritin of $2000 \mathrm{ng} / \mathrm{ml}$ was found to be the best threshold for discriminating the presence of cardiac iron with an area under the curve (AUC) of $0.733(\mathrm{P}=0.001)$ (Figure 1A) (Sensitivity= 0.73 and Specificity=0.65). Odds ratio (OR) for global heart $\mathrm{T} 2$ * values $<20 \mathrm{~ms}$ was $4.9(1.7-13.895 \% \mathrm{CI} ; \mathrm{P}=0.003)$ for serum ferritin levels $\geq 2000 \mathrm{ng} / \mathrm{ml}$.

There was a significant negative correlation between global heart and MRI LIC values $(\mathrm{P}=-0.436 ; \mathrm{p}<0.0001)$. Using ROC curve analysis, a $\mathrm{LIC} \geq 14 \mathrm{mg} / \mathrm{g} / \mathrm{dw}$ was found to be the best threshold for discriminating the presence of MIO in children with an AUC of 0.817 $(\mathrm{p}<0.0001)$ (Figure 1B) (Sensitivity $=0.74$ and Specificity $=0.85$ ). OR for abnormal global heart T2* values was 30.08 (3.58-252.68 95\% CI; $\mathrm{P}=0.002)$ for patient with MRI LIC $\geq 14 \mathrm{mg} / \mathrm{g} / \mathrm{dw}$ versus patients with normal MRI LIC.

\section{Conclusions}

A weak connection between serum ferritin levels or hepatic iron and cardiac iron was demonstrated in our pediatric population. Anyway, MRI LIC $\geq 14 \mathrm{mg} / \mathrm{g} / \mathrm{dw}$ and serum ferritin levels $\geq 2000 \mathrm{ng} / \mathrm{ml}$ were found to be significant risk factors for a global heart $\mathrm{T}^{*}$ value $<20 \mathrm{~ms}$ in TM children.

\footnotetext{
Authors' details

${ }^{1}$ CMR Unit, Fondazione G. Monasterio CNR-Regione Toscana, Pisa, Italy. ${ }^{2}$ Centro per la Cura delle Microcitemie, Cardarelli Hospital, Napoli, Italy. ${ }^{3}$ Ematologia II con Talassemia, Ospedale "V. Cervello", Palermo, Italy. "Unità Operativa Complessa di ImmunoEmatologia, Policlinico Umberto 1, Roma, Italy. "Struttura Complessa di Cardioradiologia-UTIC, P.O. "Giovanni Paolo II", Lamezia Terme (CZ), Italy. "Istituto di Radiologia, Az. Osp. "Garibaldi", Presidio Ospedaliero Nesima, Catania, Italy.
} 

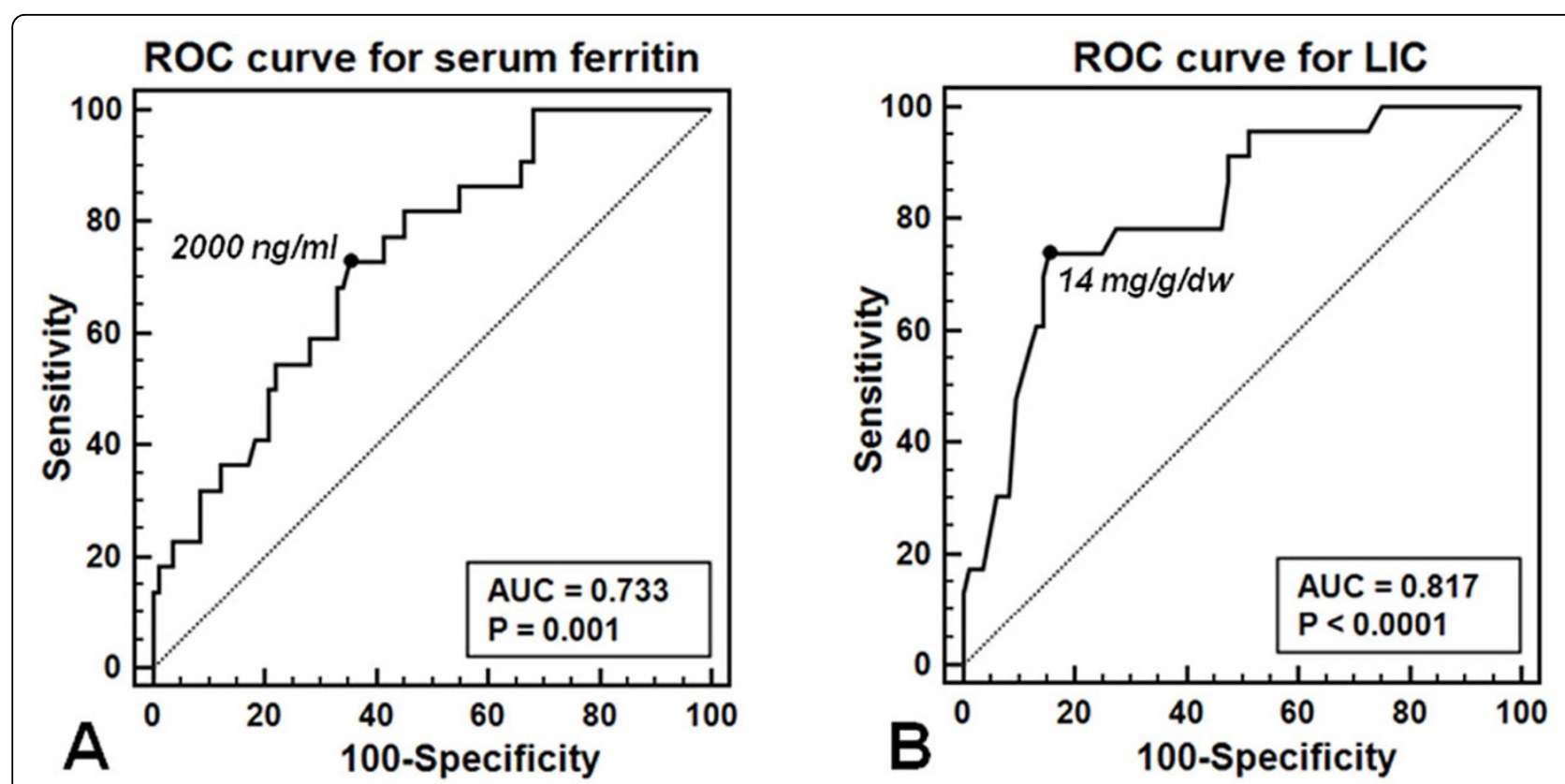

Figure 1 ROC curves for serum ferritin levels (A) and MRI LIC values (B).

Published: 27 January 2016

doi:10.1186/1532-429X-18-S1-P295

Cite this article as: Meloni et al: Association between serum ferritin and

liver iron concentration with cardiac iron in pediatric thalassemia major

patients. Journal of Cardiovascular Magnetic Resonance 2016 18(Suppl 1):P295.

Submit your next manuscript to BioMed Central and take full advantage of:

- Convenient online submission

- Thorough peer review

- No space constraints or color figure charges

- Immediate publication on acceptance

- Inclusion in PubMed, CAS, Scopus and Google Scholar

- Research which is freely available for redistribution 